УДК 398.I

ББК 82.3
ПОЧЕМУ РОДИЛСЯ ЧЕРТ: СЮЖЕТ

О КОММУНИСТЕ-СВЯТОТАТЦЕ, НОВОРОЖДЕННЫЕ МОНСТРЫ И ГРАНИЦЫ РЕЛИГИОЗНОЙ ДИДАКТИКИ

\author{
(C) 2018 г. А.А. Панченко \\ Институт русской литературы \\ (Пушкинский Дом) Российской академии наук, \\ Санкт-Петербург, Россия \\ Дата поступления статьи: I7 февраля 2018 г. \\ Дата публикации: 25 июня 2018 г. \\ DOI: IO.22455/2500-4247-20I8-3-2-252-287
}

Аннотация: В І923 г. краевед, этнограф и археолог Василий Смирнов опубликовал в сборнике трудов Костромского научного общества по изучению местного края статью «Черт родился. (Творимая легенда)». Речь в ней шла о необычном демонологическом сюжете, получившем распространение в Советской России, - о черте, родившемся в семье коммуниста. В своих комментариях к публикации Смирнов указывал на ряд параллелей в европейской фольклорной прозе; на сказания о чудотворных иконах и библейскую историю о неопалимой купине; демонологические сюжеты и поверья о суккубате и инкубате; легенды о рождении антихриста, а также христианскую эсхатологию в целом. Этих наблюдений, однако, недостаточно для интерпретации рассказов о новорожденном черте. В действительности мы имеем дело не столько с «творимой легендой», сколько со случаем международной миграции устойчивого сюжета.

Ключевые слова: антропология святотатства, фольклорная демонология, рождение монстров, бродячие сюжеты.

Информация об авторе: Александр Александрович Панченко - доктор филологических наук, профессор РАН, Институт русской литературы (Пушкинский Дом) РАН, набережная Макарова, д. 4, І99034 г. Санкт-Петербург, Россия.

E-mail: apanchenko20o8@gmail.com

Для цитирования: Панченко А.А. Почему родился черт: сюжет о коммунисте-святотатце, новорожденные монстры и границы религиозной дидактики // Studia Litterarum. 20I8. T. 3, № 2. C. 252-287. DOI: I0.22455/2500-4247-2018-3-2-252-287 


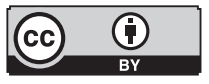

This is an open access article distributed under the Creative Commons Attribution 4.0 International (CC BY 4.0)

\section{WHY WAS A BABY DEVIL BORN: THE LEGEND ABOUT A BLASPHEMOUS COMMUNIST, MONSTROUS BIRTHS, AND THE LIMITS OF RELIGIOUS DIDACTICS}

\author{
(C) 2018. A.A. Panchenko \\ Institute of Russian Literature \\ (Pushkinskij Dom), \\ Russian Academy of Sciences \\ St. Petersburg, Russia \\ Received: February I7, 2018 \\ Date of publication: June 25, 2018
}

Abstract: In 1923, the Russian ethnologist and archaeologist Vasily Smirnov published an article entitled "A Devil is Born. (Contemporary Legend)". The article dealt with an unusual demonological legend that had appeared short time ago in Soviet Russia. It told a story of a baby devil who was an offspring of one communist. In his commentaries, Smirnov pointed at some parallels between European folk narratives, legends about miraculous icons, the story about the burning bush in the Book of Exodus, beliefs related to succubi and incubi, legends about the birth of antichrist, and Christian eschatology in general. However, those observations require certain corrections. In fact, the narrative about the baby devil is an international legend, and its history can be the ground for general discussion about evolution and functions of didactic stories in Christian culture.

Keywords: anthropology of blasphemy and sacrilege, popular demonology, baby devil, monstrous births, migratory legends.

Information about the author: Alexander A. Panchenko, DSc in Philology, Professor, Institute of Russian Literature (Pushkinsky Dom), Russian Academy of Sciences, Makarov embankment, 4, I99034 St. Petersburg, Russia.

E-mail: apanchenko20o8@gmail.com

For citation: Panchenko A.A. Why Was a Baby Devil Born: The Legend about a Blasphemous Communist, Monstrous Births, and the Limits of Religious Didactics. Studia Litterarum, 2OI8, vol. 3, no 2, pp. 252-287. (In Russ.) DOI: IO.22455/2500-4247-20I8-3-2-252-287 
Богохульство и святотатство - в качестве дискурсивных категорий и социальных практик - привлекают сравнительно малое внимание социальных антропологов, особенно - по сравнению с историками. Жанна Фавре-Саада, сетуя на это обстоятельство в своей недавней статье, высказывает предположение, что этнологам тема осквернения священного попросту кажется небезопасной: дескать, «историки не рискуют вызвать гнев “аборигенов”, когда те живут в Цюрихе XVII века или столетием позже во Франции» [55, с. 30]. На мой взгляд, однако, здесь можно говорить и о несколько иных фактоpax, a именно - эпистемологических пресуппозициях современной антропологии, восходящих к протестантизму, секуляризму и теориям прогресса. Богохульство и святотатство неосознанно понимаются исследователями как своего рода религиозные / социально-идеологические пережитки, заслуживающие прежде всего исторического внимания. На самом деле все обстоит, по-видимому, несколько иначе, о чем свидетельствует и публичная значимость категории святотатства в современных обществах: достаточно вспомнить процесс «Пусси Райот» или расстрел редакции «Шарли Эбдо». Что касается устойчивых фольклорных или литературных сюжетов на эти темы, то их тоже принято интерпретировать довольно упрощенно - как своего рода художественно-дидактические иллюстрации к религиозным запретам и нормам, где трансгрессия влечет более или менее однообразное наказание. Я, однако, думаю, что эти сюжеты могут нам рассказать о религиозных и не только религиозных дискурсах и практиках гораздо больше, и хотел бы в этом контексте остановиться на одном (тоже, впрочем, историческом) примере.

В 1923 г. костромской краевед, этнограф и археолог Василий Иванович Смирнов (1882-I94I) опубликовал в сборнике трудов гу- 
бернского научного общества по изучению местного края статью «Черт родился. (Творимая легенда)». Не берусь судить, следует ли в этом заголовке видеть отсылку к известной трилогии Федора Сологуба, однако речь действительно шла о необычном демонологическом сюжете, только что получившем распространение в Советской России. В одной из версий этой истории, записанной самим Смирновым в Костроме в 1920 г., рассказывалось следующее:

Не у нас это было, где-то тут близко в Ярославской губернии. Жили мужик да баба. Мужик, коммунист он был, изрубил иконы, побросал их в печку. Знала ли, нет ли про то баба, стала она растапливать печь, - не топятся дрова, да и только. «Что, - говорит баба, - за чудо!» А из печки голос: «Это чудо еще не чудо, а вот через три дня так будет чудо». Испугалась баба, побросала все, а через три дни и разродилась, да и родила черта - мохнатый весь. Народ прослышал про это. Собираться стал смотреть на черта. Всполошились и власти, аресты пошли - не ходи смотреть на черта. Что делать? Думали-думали мужик с бабой, взяли да и отнесли черта в лес, бросили там. Приходят домой, а черт сидит на лавке, смеется. «Вот так чудо», - говорят. - «Нет, это еще не чудо, а вот через двадцать дней так будет чудо», говорит тот. Не знают мужик с бабой, что им и делать, отказываются от черта и соседи, никто не берет. Узнало начальство и арестовало черта. А через 20 дней - это в самую Троицу... будет, - заканчивает легенда [30, с. 17].

Согласно сведениям, собранным Смирновым, рассказ о черте, родившемся в семье коммуниста, получил в I920-I92I гг. широкое распространение не только в Костромской, но и в Ярославской, Тверской и Вологодской губерниях, а также в Москве. Вместе с тем исследователь отмечает, что этот сюжет был известен и на Украине, причем в качестве места действия там называли Ярославскую, Костромскую или Пермскую губернии. Варианты рассказа, проанализированные костромским исследователем, включали два сюжетных подтипа. В первом «причиной» рождения черта было сожжение икон, а во втором (известном по единственной публикации в костромской газете «Красный мир») речь шла о неосторожных словах, произнесенных мужем-коммунистом: 
В Ярославской губернии во время партийной мобилизации на транспорт был пущен слух, что в Тутаевском уезде... жена мобилизованного на транспорт коммуниста родила черта. Дело вышло таким образом. Мужа призвал комитет, а жена просила остаться, говоря, что на днях у нее должен родиться ребенок. «А хоть черта роди, - ответил муж, - раз партия требует, я обязан явиться». И вот муж уехал, а жена родила черта с хвостом и рогами [30, c. I8].

Среди устойчивых мотивов, присутствующих в опубликованных Смирновым текстах, следует отметить формулу «это еще не чудо», произносимую потусторонним голосом «из печи», «из трубы» или «в брюхе» бабы и подразумевающую, так сказать, кумулятивную цепочку чудесных и страшных событий (в том числе и еще не произошедших); сохранность сжигаемых икон (в одном из вариантов, кроме того, из самовара, вскипяченного на углях от иконы, идет не вода, а кровь); необычные, по сравнению с человеческим младенцем, способности новорожденного черта («как родился, так и побежал в угол», «как родилось, так и заговорило»), а также неудачные попытки избавиться от него (черта бросают в лесу, топят в воде, закапывают в землю и даже режут на куски). Примечательным представляется и финальный мотив, присутствующий в большинстве версий - черта передают в музей, где все желающие могут его увидеть, либо «возят в клетке по городам». Судя по материалам Смирнова, распространение легенды действительно сопровождалось наплывом людей, желающих посмотреть на черта, в губернские и уездные музеи. Так, Ярославский естественноисторический музей с этой целью посетило около 400 человек; что-то подобное происходило и в Вологде [30, с. I8]. В более позднем варианте того же сюжета из Тверской губернии рассказывалось, «что родился поросенок с человеческой головой..., но был убит мужиком, и этого мужика будто бы расстреляли за то, что он загубил человеческую душу. Говорили, что также был после появления на свет поросенка расстрелян священник, арестованный раньше за то, что он предсказал рождение получеловека-полусвиньи. <...> Досадная молва волновала настолько, что осенью г92 г г. особое ветеринарное совещание на ржевской фирме [ферме? - А.П.] птицеводства и мелкого животноводства в Зеленкине составило акт осмотра какого-то свиного уродца, действительно родившегося там, потом заспиртованного и пе- 
реданного в ржевский музей. С появлением его в музее посещаемость музея значительно увеличилась» [30, с. I9].

В своих комментариях к опубликованным в статье материалам Смирнов указывал на ряд параллелей в европейской сказке и несказочной прозе (формула «это еще не чудо», мотив «голос из печи» или «голос из трубы»); в сказаниях о чудотворных иконах и библейской истории о неопалимой купине; демонологических сюжетах и поверьях о суккубате и инкубате (в том числе - на русском материале - в «Повести о бесноватой жене Соломонии», а также в сюжете о демоне, сожительствующем с женщиной в обличье умершего супруга); легендах о рождении антихриста, а также в христианской эсхатологии в целом. Эти наблюдения позволили костромскому исследователю заключить, что «целый ряд звеньев связывает легенду о родившемся черте с более древними прототипами: на долю современной эпохи остаются... лишь два новых явления...: музей и иконоборец-коммунист. При этом... не исключена возможность и реальной подкладки для ее появления в виде, напр<имер>, рождения уродца или волосатого ребенка. Если общие причины для появления легенд имеют более глубокие основания, так собственно внешний повод к их возникновению нередко покоится в подобных явлениях» [30, с. 20].

Публикация Смирнова имела резонанс в среде профессиональных этнографов и любителей фольклора середины 1920-х гг. О ней, например, упоминал П.Г. Богатырев в своей книге «Магические действия, обряды и верования Закарпатья», опубликованной на французском языке в Париже в 1929 г. Правда, в советском издании І97І г. этот пассаж был изъят по цензурным соображениям [32, с. I49-150]. В своем очерке «Голубиная книга», опубликованном в 1924 г. в журнале «Красная новь», статью «Черт родился» подробно пересказал М.М. Пришвин, сделавший к этой истории собственное дополнение:

Теперь от себя скажу, что легенда о родившемся черте, конечно, не миновала и моего слуха, я, например, знаю и такие подробности: в деревне Следово Смоленской губ<ернии> жена б<ывшего> военного комиссара Петра Васильевича Ермилина, Акулина, потихоньку от мужа повесила на рожденного ею ребенка крестик, чтобы предохранить его от превращения в черта; знаю, что Смоленский черт был заделан в ящик и отправлен в Москву в 
музей... Знаю, что и вот эта кустарная деревня Тверск<ой> губ<ернии>, где я сейчас переписываю свою работу, - такая же: в любой избе стоит мне только заикнуться о родившемся черте, как мне откликнутся новыми бесчисленными вариантами [26, с. 236].

Вскоре, впрочем, по вполне понятным причинам тексты о черте, родившемся у коммуниста, исчезли со страниц и научных, и литературнопублицистических изданий.

Не останавливаясь сейчас на возможных литературных продолжениях этой истории (а мне, в частности, представляется, что она с большой вероятностью могла оказать влияние на фабулу булгаковского «Собачьего сердца»), вернусь к проблеме ее интерпретации и контекстов. Казалось бы, наиболее важные соображения здесь уже были высказаны самим Смирновым. Это, однако, не так, поскольку в действительности мы имеем дело не столько с «творимой легендой», сколько со случаем международной миграции устойчивого сюжета.

В начале I89I г. провинциальные американские газеты одна за другой стали публиковать заметки о необычной истории, якобы произошедшей где-то в Миннесоте: в семье сапожника по фамилии Миллер или Моррис родился младенец, целиком покрытый волосами, с хвостом, рогами на голове, когтями на руках и копытами на ногах, короче говоря - не человек, а чертенок [57; 42; 60; 63]. За три недели до этого трагического события в дом Миллеров «зашел еврей-разносчик, торговавший цветными олеографиями распятия. Его попросили уйти, но он так навязчиво предлагал свой товар, что миссис Миллер рассердилась. Она заявила, что скорее потерпит в доме черта, чем изображение Спасителя [declared that she would Sooner Have the Devil in Her House than the portrait of her Savior]. Несчастная женщина даже не догадывалась о подлинном значении своих слов, пока не взглянула на рожденное ею чудовище» [6о]. В других версиях речь шла не о еврееразносчике с олеографиями, а о книготорговце, продающем Библию, или о молодом католическом священнике, торгующем изображениями Мадонны с младенцем. Формула проклятия, приводящего к рождению чертенка, также могла варьироваться, однако результат был всегда один и тот же. В некоторых корреспонденциях сообщалось, кроме того, что чудовище было передано в музей Смитсоновского института в Вашингтоне, в результате чего 
это учреждение посетило более 2000 человек, желавших увидеть чертенка собственными глазами.

Хотя довольно скоро эта история была объявлена недостоверным слухом, слух о рождении черта продолжал циркулировать в Северной Америке. В книге «Аномалии и курьезы медицины», написанной в I896 г. в Филадельфии докторами Джорджем Гаулдом и Уолтером Пайлом, история о новорожденном черте пересказывалась как якобы произошедшая в Австралии. Судя по всему, о распространении той же легенды свидетельствует следующее сообщение Летишии Реншалл, опубликованное в г902 г. в «Журнале американского фольклора»:

В январе в нью-йоркской «маленькой Италии» было много волнений из-за родившегося вследствие проклятия дьявольского младенца. Сообщалось, что у него есть рога, горящие огнем зеленые глаза, ноги заканчиваются раздвоенными копытами, что в двухдневном возрасте он убил соседского ребенка, на чьем горле остались следы крошечных пальчиков. Приблизительно тогда же подобные слухи ходили и в Балтиморе... [74, с. 274].

В г9І3 г. этот же сюжет был записан в Квебеке:

В деревне неподалеку от Монреаля жила женщина. Раньше она была хорошей католичкой, а потом стала серьезно пренебрегать своими религиозными обязанностями. Ее безверие достигло апогея во время ее беременности, когда она выгнала продавца религиозных картин, заявив, что лучше иметь в доме черта. Ребенок, родившийся в положенное время, обнаружил необычайное развитие. У него от рождения были зубы; он начал говорить, когда ему был месяц; вообще он настолько поразил своих родителей и их соседей, сходившихся со всех сторон, чтобы посмотреть на это чудище, что они стали всерьез подумывать о том, чтобы его убить. Ребенок подслушал разговор об этом и вмешался в него следующим образом: «Если вы убьете меня, появятся семеро худших, чем я». Он отсоветовал отдавать его в бродячий цирк в качестве «уродца», заявив, что денег на нем заработать никогда не удастся [68, с. 36о].

B I9I4 г. слухи о рождении чертенка распространились в Чикаго. Об этом эпизоде мы можем судить из первых рук благодаря воспоминаниям 
Джейн Аддамс, - лидера суфражистского движения и одного из пионеров социальной работы в США, - основавшей в I889 г. благотворительный Халл-хауз (он, в частности, был прообразом московского «Сетлемента» С.Т. Шацкого и А.У. Зеленко, а также Лиговского народного дома графини Паниной в Петербурге). В чикагском случае учреждением, куда был передан чертенок (the Devil Baby), считали именно Халл-хауз, так что в течение полутора месяцев I9I4 г. Аддамс имела возможность наблюдать за непосредственным социальным эффектом легенды, а также знакомиться с ее разными вариантами. Выяснилось, что здесь имели хождение те же самые сюжетные подтипы, что и в позднейших русских вариантах, - с уничтожением священного изображения и без него (в данном случаем они фигурировали как «итальянская» и «еврейская» версии). Сама Аддамс суммировала их следующим образом:

Итальянская версия, известная в сотне вариантов, рассказывала о благочестивой итальянке, вышедшей замуж за атеиста. Ее муж в гневе разорвал священное изображение, висевшее на стене в спальне, и заявил, что скорее потерпит в доме черта, чем такую вещь, после чего дьявол воплотился в его будущем ребенке. Сразу же после рождения чертенок стал бегать по столу, грозя своему отцу пальцем с глубокой укоризной. В конце концов, отец поймал его и, охваченный страхом и трепетом, отнес в Халл-хауз. Когда обитатели последнего, невзирая на ужасающую внешность младенца, вознамерились спасти его душу и отнесли его в церковь, чтобы окрестить, они обнаружили, что чертенок сбежал от святой воды и беспечно скачет по спинкам церковных скамеек.

Еврейская версия, также имеющая варианты, рассказывает об отце шести дочерей, сказавшем перед рождением седьмого ребенка, что лучше иметь в семье черта, чем еще одну дочь, после чего чертенок сразу же и появился [39, с. 3-4].

Наконец, в I94I г. этот же сюжет был записан студентом Университета Индианы от тридцатидевятилетней афроамериканки, родившейся и выросшей в Джорджии:

В Арканзасе странствующий торговец остановился у дома одной женщины и спросил, не хочет ли она купить Библию. Женщина была беременна. 
Она сказала, что скорее потерпит в своем доме черта, чем проклятую Библию. Когда ребенок родился, у него были длинные уши, рога и хвост. Потом и женщина, и ее ребенок умерли [58, с. 87].

В указателе фольклорных сюжетов и мотивов Англии и Северной Америки, составленном Эрнстом Боманом в І966 г., сюжет о продавце картин или Библий учтен под номером G 303.25.2I.I* («Мать-богохульница производит на свет ребенка-монстра» / Blasphemous mother bears monster child) [45, с. 29I; см. также: 46]. Хотя Боман ссылается только на вышеупомянутые американские записи, сходные сюжеты известны и в европейской культуре Нового времени. Так, в I642 г. англиканский священник Джон Локк написал брошюру о «странном и прискорбном случае», якобы произошедшем в Нортгемптоншире: некая Мэри Уилмор, считавшая, вслед за радикальными пуританами, что младенцев не нужно крестить, заявила: «Пусть лучше мой ребенок родится безголовым, чем будет осенен крестным знамением» [I had rather my childe should be borne without a head, then to have a head to be signed with the signe of the Crosse]. Когда она разрешилась от бремени, то младенец действительно оказался безголовым [64]. Четыре года спустя появился ответный памфлет о женщине-папистке, пожелавшей, чтобы ее будущий ребенок скорее был безголовым, чем «круглоголовым». У новорожденного, согласно брошюре, действительно не оказалось головы, а лицо располагалось в области грудной клетки [38]. Похожая история была известна в те времена и в континентальной Европе: «нечестивая женщина кричала, что скорее родит теленка, чем будет молиться святой Маргарите (традиционно считавшейся покровительницей беременных) - с теми же предсказуемыми результатами» [44, с. 52].

Еще один сюжет этого рода был опубликован американским фольклористом Хербертом Халпертом в І958 г. Речь здесь шла об истории, якобы случившейся в Кентукки в начале I930-х гг. Одна из здешних баптистских церквей совершала обряд крещения на небольшой речке. На этом собрании присутствовал пьяный местный житель по имени Арт Редферн. Он богохульствовал, насмехался над проповедником и всеми собравшимися. «Потом он увидел черепаху. Он взял ее и распял на сикоморе прямо перед толпой. В то время его жена была беременна. Когда младенец родился, оказалось, что у него маленькая пятнистая голова - как у черепахи. Он так 
и не научился ходить и всю жизнь ползал» [58, с. 240]. Халперт, впрочем, полагал, что подобные сюжеты нужно рассматривать отдельно от историй о рождении чертенят и интерпретировать их как особую группу рассказов о «проклятых детях», наказанных за грехи родителей. Исследователь включил сюда сюжеты о беременной женщине, прогоняющей от своих дверей однорукого нищего или торговца (в результате чего ее ребенок рождается с дефектной рукой), издевательски сравнивающей семью бедняков со свиньей и поросятами (новорожденный появляется на свет со «свиной головой» либо копытцами вместо ступней) и т. п. [58, с. 233-24I].

Наконец, говоря об американской традиции, можно вспомнить и более ранний сюжет о новорожденном чертенке. Это легенда о так называемом «джерсийском дьяволе», появившаяся, по-видимому, еще в XVIII в. В ней рассказывается о многодетной матери по имени Джейн Лидс, проклявшей в утробе свое тринадцатое дитя и в результате также родившей демона. Сначала новорожденный выглядел как обычный ребенок, но затем превратился в монстра со змеиным телом, лошадиной головой, свиными конечностями и крыльями летучей мыши:

Сбежав от матери, чудовище убивало детей и причиняло многочисленные бедствия сельскому хозяйству. В последующие годы этому существу приписывали различные зловещие звуки и таинственные происшествия, в которых видели предвестия несчастий, кораблекрушений и войн. «Звездный час» джерсийского дьявола, судя по всему, пришелся на г909 г., когда газеты южного Нью-Джерси и восточной Пенсильвании были заполнены сообщениями о людях, видевших это чудовище [46, с. 427].

Таким образом, американские легенды о проклятых детях, имевшие достаточно широкое распространение на рубеже XIX и XX вв., представляют собой достаточно близкую аналогию русскому демонологическому сюжету, исследованному Смирновым. Стоит, однако, обратить внимание и на более широкий культурно-исторический контекст рассматриваемых мотивов, связанный, помимо всего прочего, с представлениями о последствиях номинации и призывания нечистого духа. В указателе Стита Томпсона им соответствует несколько мотивов: С 758 . ( «Рождение монстра вследствие неосторожного (безрассудного) желания родителей»); M4II.I 
(«Родительское проклятье»); S223 («Бездетная пара обещает дьяволу ребенка, если им удастся его зачать») и его различные подтипы; а также Т556 («У женщины рождается демон»). Очевидно, что этот перечень отсылает к достаточно широкому спектру возможных сюжетных вариаций. В нашем случае, однако, важнее определить и проанализировать «ближайший круг» возможных параллелей к истории о новорожденном чертенке.

Очевидная аналогия в средневековой европейской традиции - начальные мотивы сюжета о Роберте Дьяволе ности, вошедшего в сборник exempla Этьена де Бурбона, а также имевшего распространение в форме миракля [3I, с. 2I4-215]. Эта история «начинается с сообщения о свадьбе родителей Роберта и их продолжительной бездетности, с мольбы матери о ребенке, не важно, от Бога или от дьявола, и ее обещании отдать дьяволу ребенка, рожденного с его помощью. Родившийся таким образом ребенок появляется на свет, будучи уже одержим злом. Он отличается необычайной силой и развитием и с самого начала обнаруживает свою дьявольскую природу в жестоких и злых поступках. Достигнув самого дна человеческой греховности, он осознает внушаемый им ужас, заставляет мать рассказать историю своего рождения и затем обращается к долгому и тяжелому покаянию» [6I, с. 52]. Вместе с тем историю о Роберте Дьяволе необходимо, по всей видимости, рассматривать в более широком контексте фольклорных сюжетов о грехе, покаянии и посмертной судьбе, в частности - типа ATU 756 В («Разбойник Мадей») [40]. Здесь мотив посвящения еще не рожденного ребенка демоническим силам или сатане служит лишь прологом к фаталистическим нарративам об избавлении от проклятия и загробных мук. С другой стороны, тема святотатства и осквернения сакрального предмета в подобных сюжетах специально не акцентируется. Поэтому вряд ли стоит думать, что история о рождении Роберта Дьявола и подобные ей оказали сколько-нибудь существенное влияние на исследуемый сюжет.

Думаю, что преимущественно факультативное значение здесь имеют и широко распространенные в европейской культуре представления об инкубате, т. е. о физическом сожительстве женщины и демона и рождающихся от этого союза детях. Если, скажем, - обратиться к упомяну-

I У Томпсона это подтип S.223.O.I («Роберт Дьявол. Бездетная пара хочет иметь ребенка, даже если его пошлет дьявол. Новорожденный имеет демоническую природу»). 
той Смирновым «Повести о бесноватой жене Соломонии», - при всем ее восточно-христианском и севернорусском колорите, а также существенных отличиях от западных демонологических трактатов, - мы увидим, что и в ней не содержится мотивов святотатства и нарушения запрета: бес склоняет героиню к соитию обманом, выдав себя за новобрачного. «Основной комплекс демонологических сюжетов Повести, - отмечает А.В. Пигин, обязан своим происхождением двум средневековым представлениям - о сожительстве людей с бесами и о бесноватости (одержимости)» [25, c. I05]. В нашей истории о новорожденном чертенке, наоборот, ничего не говорится об инкубах или одержимости демонами. Младенец-монстр рождается у вполне заурядной пары, никогда ранее не имевшей каких-либо контактов с бесами. Поэтому здесь скорее стоило бы видеть возможные аналогии с сюжетами о проклятых родителями и / или «подмененных» демонами детях. К этому я еще вернусь ниже.

Итак, собственно демонологические контексты исследуемого сюжета представляются не то чтобы сугубо случайными или вторичными, но все же не играющими решающей роли в его формировании и дистрибуции. Чем тогда могут быть обусловлены генезис и популярность этой истории? Прежде всего стоит указать на вариативность мотивов святотатства / богохульства в пересказанных выше американских текстах: объектом словесного либо физического поругания может оказаться и священное изображение, и священная книга, т. е. Библия. В контексте американской культуры рубежа XIX и XX вв. эта вариативность, как мне представляется, указывает на скрытую полемику между католиками, почитающими священные изображения, и протестантами, исповедующими принцип sola Scriptura. При этом в приведенных выше примерах из европейской культуры XVII в. можно видеть признаки сходной полемики, касающейся в данном случае крестного знамения и почитания святых. Можно предположить, таким образом, что происхождение (или, по крайней мере, широкое распространение) исследуемого сюжета тем или иным образом связано с историей Реформации.

Тема врожденных телесных аномалий получила большую и довольно специфическую популярность в европейской культуре XVI-XVII вв. ${ }^{2}$ O рождении монстров, конечно, писали и средневековые авторы, тракто-

2 О топике и символике чудовищного и монструозного в этот период см.: [66; 69; 67; II; $73 ; 51 ; 72 ; 14 ; 70]$. 
вавшие такие случаи - наряду с необычайными природными явлениями - как знаки божественного гнева: предзнаменование войн, голода, политических потрясений и даже конца света³. Среди часто цитировавшихся в этом контексте пассажей был фрагмент из неканонической 3-й (она же 2-я и 4-я) книги Ездры: «А если Всевышний даст тебе дожить, то увидишь, что после третьей трубы внезапно воссияет среди ночи солнце и луна трижды в день; и с дерева будет капать кровь, камень даст голос свой, и народы поколеблются. Тогда будет царствовать тот, которого живущие на земле не ожидают, и птицы перелетят на другие места. Море Содомское извергнет рыб, будет издавать ночью голос, неведомый для многих; однако же все услышат голос его. Будет смятение во многих местах, часто будет посылаем с неба огонь; дикие звери переменят места свои, и нечистые женщины будут рождать чудовищ» (3 Ездр. 5, 4-8) [66, с. 25]. Однако в течение XVI в.

3 Вполне типичным примером такого рода в древнерусской письменности можно считать запись «Повести временных лет» под го65 г., содержащую частично восходящее к Хронике Георгия Амартола рассуждение о недобрых предзнаменованиях (цитирую в переводе Д.С. Лихачева): «В те же времена было знаменье на западе, звезда великая, с лучами как бы кровавыми; с вечера всходила она на небо после захода солнца, и так было семь дней. Знамение это было не к добру, после того были усобицы многие и нашествие поганых на Русскую землю, ибо эта звезда была как бы кровавая, предвещая крови пролитье. В те же времена ребенок был брошен в Сетомль; этого ребенка вытащили рыбаки в неводе, и рассматривали мы его до вечера и опять бросили в воду. Был же он такой: на лице у него были срамные части, а иного нельзя и сказать срама ради. Перед тем временем и солнце изменилось и не стало светлым, но было как месяц, о таком солнце невежды говорят, что оно объедено. Знамения эти бывают не к добру. Мы потому так думаем, что именно так случилось в древности, “при Антиохе, в Иерусалиме: внезапно по всему городу в течение сорока дней стали являться в воздухе всадники скачущие, с оружием, в золотых одеждах, полки обеих сторон являлись, потрясая оружием: и это предвещало нападение Антиоха, нашествие рати на Иерусалим. Потом при Нероне цесаре в том же Иерусалиме над городом воссияла звезда в виде копья; это предвещало нашествие римского войска. И снова так было при Юстиниане цесаре: звезда воссияла на западе, испускавшая лучи, и прозвали ее лампадой, и так блистала она дней двадцать; после же того было звездотечение на небе с вечера до утра, так что все думали, будто падают звезды, и вновь солнце сияло без лучей: это предвещало крамолы, болезни людям, смерти. Снова, уже при Маврикии цесаре, было так: жена родила ребенка без глаз и без рук, а к бедрам у него рыбий хвост прирос; и пес родился шестиногий; в Африке же двое детей родилось: один о четырех ногах, а другой о двух головах. Потом же было при царе Константине Иконоборце, сыне Леона, звездотечение на небе, звезды срывались на землю, так что видевшие думали, что конец мира; тогда же воздухотечение было сильное; в Сирии же было землетрясение великое, так что земля разверзлась на три поприща, и, дивно, из земли вышел мул, говоривший человеческим голосом и предсказывавший нашествие иноземцев, как и случилось потом": напали сарацины на Палестинскую землю. Знамения ведь на небе, или в звездах, или в солнце, или в птицах, или в чем ином не к добру бывают; но знамения эти ко злу бывают: или войну предвещают, или голод, или смерть» [23, с. 179]. 
такое - «пассивное» и исключительно провиденциалистское - прочтение монструозности - претерпевает существенные изменения, причем к созданию нового дискурса о чудовищах были причастны, в том числе, и основатели протестантизма Мартин Лютер и Филипп Меланхтон, напечатавшие в I523 г. памфлет «Объяснение по поводу двух отвратительных животных». В нем сообщалось, что во Фрайбурге родился теленок с монашеским капюшоном, а из Тибра выловили монстра с ослиной головой, женской грудью и ногами, покрытыми рыбьей чешуей. Понятно, что и то, и другое чудовище были истолкованы здесь не только в общем эсхатологическом контексте, но и как специальные знаки греховности католической церкви [70, с. 59-72]. С легкой руки Лютера и Меланхтона монструозность оказалась важной темой для европейской религиозной полемики XVI-XVII вв. и стала все чаще ассоциироваться не только с представлениями о божественном промысле, предопределении и необходимости коллективного покаяния, а с понятиями индивидуального греха и повседневной морали. Наряду с этим происходила постепенная «секуляризация» или «натурализация» монструозности:

Смена прилагательных, использовавшихся для характеристики монстров в заголовках французских и английских книг и площадных листов, позволяет проследить переход от страха к развлечению, от предзнаменования к диковинке, от проповеди к застольной беседе. К концу XVI в. эпитеты «жуткий», «ужасный», «страшный», «пугающий» уступают место «необыкновенному», «диковинному», «удивительному». Этот сдвиг указывает на изменения в интерпретации. Хотя Бог, разумеется, по-прежнему сохранял полную ответственность за появление монстров на свет, акцент смещался с конечных причин (божественная воля) на непосредственные (физические объяснения и естественный порядок). Природа уже не была простым отражением божественных намерений и постепенно стала восприниматься как автономная сущность, обладающая собственной волей и чувством юмора. Этот новый взгляд вызвал к жизни обширную и разнородную группу текстов - книги о тайнах и чудесах природы [66, с. 35].

Новости о рождении чудовищ обсуждаются в ту эпоху не только учеными и богословами, они становятся важной темой для нарождающейся массовой литературы - печатных площадных листов и баллад, причем осо- 
бую популярность истории о монстрах приобретают в английской печати XVII в. Одновременно формируется и традиция публичного показа монстров как формы развлечения горожан. При этом собственно религиозные объяснения монструозности (как божественного знака или наказания) в XVI-XVII вв. достаточно часто смешиваются с натуралистическими, в том числе с восходящей к еще античным авторам идее «материнского воображения». О том, что рождение чудовищ может быть обусловлено «фантазиями» или «видениями» матери в момент зачатия, писал, например, Амбруаз Паре в книге «О монстрах и чудесах» (I573) - одном из самых известных и влиятельных тератологических трактатов своего времени [62, с. I3] ${ }^{4}$. В этом контексте наши истории о материнском проклятье как бы подразумевали двойное толкование: речь могла идти и о наказании за богохульство, и о биологических следствиях невоздержанного воображения матери.

Мне кажется, таким образом, что культурно-исторические контексты и дидактическая логика исследуемого сюжета непосредственно связаны с особенностями восприятия и репрезентации монструозности в европейской культуре второй половины XVI-XVII вв. В этом смысле можно согласиться с Халпертом: речь идет именно о новорожденных жертвах родительского проклятия, однако специфика подобных историй обусловлена двумя факторами: изменениями в отношении к физическому уродству и монструозности, а также реформационной и постреформационной полемикой о религии и ритуале. С точки зрения сюжетной логики, вышеупомянутые английские истории о безголовых младенцах очень близки нашему рассказу о новорожденном чертенкег.

В отличие от Западной Европы Нового времени, Россия XVIII-XIX вв. не знала площадных листов и картинок, посвященных рождению монстров и уродов. Единственный не переводной текст такого типа, учтенный Д.А. Ровинским, сообщал «о рождении в г730 г. в Нижнем Новгороде урода, “имущаго мужское естество, четыре руки и две головы” - урод этот отослан в Москву в декабре того же года, в двойном вине [т. е. в спиртовом растворе. - А.П.], согласно указу гз-го февраля I7І8 года о присылке всех

\footnotetext{
4 Анализ тератологических идей Паре в целом см.: [4].

5 Стоит добавить, что в европейских площадных листах XVI-XVII вв. также можно встретить сообщения о новорожденных чертенятах. Такая история, например, якобы произошла в голландском Арнеме в 1575 г. [44, с. 239].
} 
монстров в Петербургскую кунсткамеру» [27, кн. II, с. 57; кн. V, с. 74; 28, стб. I39-І40]. Очевидно, что появление этого листка было, так сказать, спровоцировано и упомянутым указом, и вообще научными и медицинскими проектами Петра I, стоявшего, по выражению Анник Морар, «у истоков демонстрации монструозного в России» [2I; см. также: 4I; 5, с. 23-45]. Однако вплоть до второй половины XIX в. Кунсткамера так и оставалась едва ли не единственным в государстве местом публичного показа и обсуждения живых и мертвых монстров (которых, впрочем, туда исправно присылали). К.А. Богданов полагает, что «простонародная медицина требовала или, во всяком случае, молчаливо допускала убивать уродов при рождении вплоть до конца XIX в.» [5, с. 36]. Это, вероятно, излишне категоричное суждение: из истории той же Кунсткамеры мы знаем о случаях, когда новорожденных с серьезными телесными дефектами не только не убивали, но и крестили в церкви. Так, в I772 г. в Берг-коллегию из Екатеринбурга было послано тело сиамских близнецов. «Близнецы родились живыми в семье жителя Невьянского завода, были крещены и “нареченным имена Федорами”. В рапорте лекарь Екатеринбургского госпиталя сообщил, что у них головы и груди разные, а тело одно с единственным задним проходом. Рук четыре, ноги три, а у третьей ноги оказалась приросшая четвертая, стопа которой имеет десять пальцев. Близнецы прожили семь дней, после смерти были положены в спирт и в силу указа Петра I отправлены в Санкт-Петербург в Академию наук» [15, c. 328; о подобных случаях см. также на с. I26, 375]. Вместе с тем крестьянские представления о причинах врожденных физиологических дефектов были далеки и от религиозной дидактики, и от медицинских теорий Нового времени. Об одном из широко распространенных объяснений телесного уродства новорожденных вредоносном колдовстве - упоминалось уже в петровском указе I7I8 г.: «Понеже известно есть, что как в человеческой породе, так в звериной и птичьей случается, что родятся монстры, то есть уроды, которые всегда, во всех государствах собираются для диковинки, чего для пред несколькими летами уже указ сказан, чтобы такие приносили, обещая платеж за оные, которых несколько уже и принесено, а именно: два младенца, каждый о двух головах; два, которые срослись телами. Однако ж в таком великом государстве может более быть, но таят невежды, чая, что такие уроды родятся от действа диавольского, чрез ведовство и порчу, чему быть невозможно...» 
[I5, c. 28]. Не менее распространенными были и поверья о демонах, «подменяющих» человеческого младенца вскоре после родов и даже в утробе матери [9; го, с. 363-367]. «Считалось, что нечистая сила... стремится заполучить младенца сразу после его рождения либо в период до крещения (реже - в первый год жизни, в двух-трехлетнем возрасте). По поверьям южных славян, подмена детей чаще случалась у тех матерей, которые не соблюдали запретов, предписанных беременным или роженицам в период первых сорока дней после родов, а также у женщин, которых во время беременности проклинали мужья... На Русском Севере верили, что причиной подмены ребенка может стать родительское проклятье, когда мать в сердцах пошлет плачущего или непослушного ребенка к черту, к лешему и т. п.» [9, с. 99]. Существовало поверье и о том, что «обмен» или «подменыш» может родиться у матери, призвавшей нечистых духов во время беременности. Так, в корреспонденции Тенишевского бюро из Череповецкого уезда сообщается, что «крестьянка родила чрезвычайно уродливого ребенка - лицо там, где затылок, одна нога много короче другой, на ступнях нет пяток и пальцев, руки без пальцев, как лопаточки. Причину рождения урода объяснили так: во время беременности <женщина> похабно ответила на вопрос матери: “А рожу какого ни на есть чертенка” [I7, с. 96]. Стоит добавить, что нарративы и верования, связанные с подменышами, не ограничивались констатацией физического уродства и / или девиантного поведения младенца. Чаще всего таких «демонических детей» все же не убивали, а пытались, так сказать, обменять обратно при помощи различных магических техник. «Например, рекомендовалось бить подкидыша розгами в ритуально значимых локусах (дома возле горящей печи, на пороге, во дворе на мусорной или навозной куче, на мосту, на перекрестке дорог, в поле на меже и т. п.) до тех пор, пока демон-виновник подмены не заберет его и не вернет людям их ребенка» [9, c. Іоо]. «Похожий способ (сопровождаемый угрозами обменышу) находим в быличке из Новгородской области: «Вот приходит сестра домой, а ребенок под кроватью уже лежит. Ну, когда крадет черт ребенка-то, так свово чертенка подкладывает. Вот если ребенок под кроватью, надо поднять его и сказать: “Сейчас брошу!” Ну кака мать захочет, чтобы ейного ребенка убили, и если подменила она ребенка, так обратно поменяет» [Іо, с. 366-367]. Наконец, иногда считалось, что от демонического подкидыша вообще не стоит избавляться, поскольку он может принести семье богатство и благополучие. 
Надо сказать, что подобные поверья существовали не только у славян. Они были распространены в различных регионах Европы и в Средние века, и позднее [56; 53]. Так, в «Молоте ведьм» читаем:

Если спросят, случаются ли при помощи демонов подмены детей и может ли демон переносить с места на место людей, даже против их воли, то на первый вопрос нужно ответить утвердительно, ибо и Вильгельм Парижский, в последней части сочинения «О Вселенной», говорит, что при попущении Божием демон может подменить ребенка и перенести с места на место. Такие дети всегда ужасно плачут, и молока четырех или пяти матерей едва ли хватило бы накормить их; они нисколько не толстеют, но делаются необычайно тяжелыми. Из-за чрезмерного ужаса, какой они могут испытать, матерям этого не следует ни утверждать, ни отрицать, но указывать, чтобы они искали совета у сведущих людей. Бог же допускает подобное за грехи родителей, когда, например, мужья проклинают своих беременных жен, говоря: «Хотел бы, чтобы ты черта носила» и подобное; нечто подобное иногда произносят и несдержанные женщины [36, с. г90].

О том, что демоны могут подменить человеческого ребенка, рассуждал и Лютер, не смешивавший, однако, эту идею с вопросом о провиденциальном и моральном значении рождения монстров [65]. Дело, впрочем, не только в Лютере: вышеописанные европейские сюжеты XVI-XVII вв. о чудовищных младенцах, судя по всему, вообще не акцентировали мотив возможной подмены: речь шла либо о наказании за грехи, либо об «игре природы», либо о том и другом одновременно.

Таким образом, история «творимой легенды» о черте, родившемся в семье атеиста, представляется мне следующей. Ее русская версия появляется под влиянием западных (вероятнее всего - американских) прототипов конца XIX - начала XX в. О том, каким именно образом этот сюжет попал в СССР, мы не знаем, однако здесь можно назвать несколько возможных вариантов. Среди них - газетные корреспонденции, повторяющие соответствующие американские публикации, непосредственное влияние книги Аддамс, чьи проекты, как мы помним, пользовались популярностью в среде российской интеллигенции, персональные контакты религиозных деятелей - католиков и протестантов (в том числе баптистов и пятидесят- 
ников) - с единоверцами из СССР. С другой стороны, не исключено, что миграция сюжета могла происходить при посредстве тех или иных европейских культур. Стоит помнить, что речь идет об эпохе Первой мировой войны, способствовавшей, без сомнения, более интенсивному обмену различными фольклорными текстами, в том числе и легендами.

Вместе с тем генезис рассматриваемого сюжета обусловлен конкретными историческими обстоятельствами: меняющимся отношением и публичным интересом к уродству новорожденных в Европе Нового времени, полемикой и религиозными войнами между католиками и протестантами, а также сосуществованием и взаимодействием различных национальных и конфессиональных культур в США в конце XIX - начале XX в. В этой перспективе представляется интересным вопрос о причинах и средствах успешной, хотя и кратковременной адаптации этой истории в России.

Очевидно, что Гражданская война, сопровождавшаяся антицерковной кампанией со стороны большевистского режима, может рассматриваться не только как социально-политический, но и как религиозный конфликт. Если не принимать во внимание случаи насильственного противостояния старообрядцев и «никониан» в XVII-XVIII вв., это была первая религиозная война в российской истории 6 . Поэтому распространение сюжета, генетически восходящего к эпохе межконфессиональных конфликтов, именно в таком историческом контексте выглядит вполне ожидаемым. Вместе с тем стоит задуматься и о других «рецептивных контекстах» этого рассказа. Об одном из них - восточнославянских представлениях о подменышах и силе родительского проклятия - речь уже шла выше. Стоит, однако, обратить внимание, что в российском контексте сюжет претерпел своего рода эволюцию: мотив проклятия вытесняется мотивом святотатства, и если в США рождение чертенка происходит вследствие неосмотрительных слов родителей (в ранних версиях матери, а в позднейших - и отца), произносящих формулу проклятия, то в советских вариантах речь уже преимущественно идет лишь о наказании за попытку уничтожить иконы. Это заслуживает

6 Здесь стоит напомнить, что в русской религиозной культуре XVIII-XIX вв. демонстративное иконоборчество было характерно для многих низовых движений и групп протестантского характера - от московских кружков Тверитинова и Зимы до баптистов рубежа XIX и ХХ вв. [29, с. 265-284; І6, с. 63-87, 96-99; 75, с. І1о, І76, 212, 380; 50, с. 85-86). Насколько мне известно, однако, «иконоборческие традиции» такого рода не приводили к появлению и распространению историй о новорожденных монстрах. 
специального комментария, поскольку логическая связь между «преступлением» и «наказанием» здесь не вполне очевидна.

С некоторой долей огрубления можно, вероятно, сказать, что многие христианские сюжеты о наказании за святотатство основаны на своеобразном принципе симметрии, регулируемом в свою очередь метафорой либо метонимией, т. е. - в терминах Дж. Фрэзера - законами гомеопатической (подобие) или контагиозной (смежность) магии [35, с. I9-53]. Нередко такое наказание имеет характер физического увечья, и в таких случаях либо поражается та часть тела (скажем, рука), при помощи которой был нанесен урон священному объекту, либо увечье дублирует / воспроизводит нанесенный ущерб. Эти принципы вполне применимы и к значительной части крестьянских рассказов о наказании советских святотатцев, вызванных к жизни атеистическими кампаниями сталинского и хрущевского времени [I2; 22; 34; 37; 6]. Здесь, впрочем, законы подобия и смежности соблюдаются не столь уж буквально, так что карой за осквернение храма или уничтожение иконы может стать просто внезапная, преждевременная или мучительная смерть самого святотатца или членов его семьи. В историях такого рода мы встречаем и рождение увечных детей, однако сюжет о новорожденном черте, насколько мне известно, здесь не встречается. Стоит добавить, что и католическая, и православная традиции в целом вполне допускали, так сказать, ритуализованную агрессию в отношении священных предметов и изображений, включая и угрозы насилием, и демонстративное поругание, и даже уничтожение [33, с. II4-II6, I82-I86; 29, с. 2I4-2I9; 7, с. I67-I72; I8]. Такая форма «ритуального диалога» вовсе не обязательно подразумевала симметричную агрессию со стороны иконы, статуи или стоящих за ними потусторонних сил: священное изображение могло, наоборот, уступить насилию и выполнить то, что от него требовалось.

В нашем случае, однако, речь идет о симметрии несколько иного рода: уничтожение изображения приводит к рождению младенца-монстра. Адаптация этой сюжетной логики в восточнославянской культуре заставляет задуматься о несколько ином аспекте крестьянского отношения к иконам, а именно о восприятии последних в качестве живых существ. В терминах когнитивного религиоведения икона одновременно предстает и материальным объектом, обладающим контр-интуитивными (в том числе орнито- или ихтиоморфными) характеристиками [см. 24, с. I79-I8I], и ан- 
тропоморфным «агентом полного доступа к стратегической информации», участвующим в ритуальных практиках и повседневной жизни людей в качестве «заинтересованного наблюдателя» [49, с. 5I-92, I37-202]. Это вызывает к жизни представления об особой - «двойной» - телесности икон (и, вероятно, некоторых других священных изображений) [см., например: I; I9]. Такая телесность, однако (как и телесность / когнитивные способности умерших [ср.: 43]), отличается от человеческой и наделяется особыми онтологическими характеристиками в различных культурных и социальных контекстах. К числу подобных характеристик в традициях иконопочитания относятся, например, зрение и способность к телесным выделениям (слезы, кровь и т. п. в сказаниях о чудотворных образах).

Эти особенности массовой «онтологии и физиологии иконы» и их роль в коммуникации людей со священными изображениями заслуживают, как мне представляется, отдельного обсуждения. Вместе с тем логично задаться вопросом о том, какие именно изображения и иконографические типы представляли себе рассказчики этой истории. Если, скажем, речь идет о Богородице, можно, в частности, предположить, что образ новорожденного черта как-то корреспондирует с изображением Христа в виде младенца, покоящегося в материнской утробе.

Не исключено при этом, что речь здесь не обязательно должна идти об особенностях русского иконопочитания или восточнославянской аграрной культуры. Возможно, что формула проклятия тоже присутствовала не во всех американских версиях этого сюжета (где, кстати, встречаются указания на конкретные иконографические типы - распятие Христа и Мадонна с младенцем) и что мы имеем дело с какими-то более общими культурными и когнитивными факторами, связанными с представлениями о священных изображениях в различных христианских культурах. Сходную идею высказывала, например, американская исследовательница «монструозного воображения»:

Хотя многие специалисты указывали на связь между Реформацией и внезапным ростом количества сочинений о монструозности, а также отмечали, что тема новорожденных уродов часто фигурировала в полемике того времени, более специальное соотношение представлений о матери монстра с реформационной войной против изображений не привлекало критического 
внимания. Важно иметь в виду, что эта иконоборческая война с самого начала велась против изображений Девы Марии, беременной матери, чьи статуи иногда можно было открыть, чтобы увидеть Пресвятую Троицу в утробе. <...> Как уже неоднократно писали, иконоборческая революция, опустошившая европейские церкви шестнадцатого столетия, преимущественно подразумевала уничтожение женской католической иконографии. Кроме того, это уничтожение сопровождалось формированием маскулинизированной религии... <...> Наконец, образ матери монстра представляет собой кощунственную пародию на культ Девы Марии. Лишая своего отпрыска всех черт законного отца, такая мать и воспроизводит, и осмеивает непорочное зачатие $[62$, c. $27-30]$.

Достаточно очевидным представляется и эсхатологический подтекст советских рассказов о родившемся черте. Этим, судя по всему, они тоже отличаются от своих американских прототипов. В двух опубликованных Смирновым вариантах формула «это еще не чудо», подразумевает, что необыкновенные события, вызванные сожжением икон, не закончились, а главное - только впереди. В одном из них (см. выше) настоящее чудо должно случиться в ближайший праздник Троицы, во втором новорожденный черт сообщает своим родителям следующее: «не бойтесь, молитесь день и ночь, через шесть недель будет чудо» [30, с. I7]. Этот подтекст вполне укладывается в традицию массовых эсхатологических ожиданий, характерных не только для первого послереволюционного десятилетия [см.: 7I], но, по-видимому, и для России конца XIX - начала XX вв. [20]. Об ожидании светопреставления именно на Троицу писал, например, один из корреспондентов Тенишевского бюро [20, с. 255]. В нашем случае, однако, примечательно и то, что эсхатологическое восприятие рождения монстра здесь как бы продолжает вышеупомянутую средневековую традицию. О существовании таких ассоциаций в России второй половины XIX в. свидетельствует, судя по всему, и эпизод из «Братьев Карамазовых», где рассказывается о шестипалом ребенке, родившемся у слуги Григория Кутузова:

Детей им бог не дал, был один ребеночек, да и тот умер. Григорий же видимо любил детей, даже не скрывал этого, то есть не стыдился выказывать. <...> Собственный же ребеночек порадовал его лишь одною надеждой, когда 
Марфа Игнатьевна еще была беременна. Когда же родился, то поразил его сердце скорбью и ужасом. Дело в том, что родился этот мальчик шестипалым. Увидя это, Григорий был до того убит, что не только молчал вплоть до самого дня крещения, но и нарочно уходил молчать в сад. Была весна, он все три дня копал гряды в огороде в саду. На третий день приходилось крестить младенца; Григорий к этому времени уже нечто сообразил. Войдя в избу, где собрался причт и пришли гости и, наконец, сам Федор Павлович, явившийся лично в качестве восприемника, он вдруг заявил, что ребенка «не надо бы крестить вовсе», - заявил не громко, в словах не распространялся, еле выцеживал по словечку, а только тупо и пристально смотрел при этом на священника.

- Почему так? - с веселым удивлением осведомился священник.

- Потому это... дракон... - пробормотал Григорий.

- Как дракон, какой дракон?

Григорий промолчал некоторое время.

- Смешение природы произошло... - пробормотал он, хоть и весьма неясно, но очень твердо, и видимо не желая больше распространяться [I3, T. I4, c. 88].

В качестве параллели к этому пассажу комментаторы академического собрания сочинений Достоевского приводят лишь цитату из «Поэтических воззрений славян на природу» А.Н. Афанасьева (где, кстати, речь идет о вере в подменышей у европейских народов): «Всякий ребенок, родившийся с физическими и душевными недостатками, в глазах суеверного народа был существо, в котором поселился нечистый дух» [13, т. I5, c. 54I]7. Этой параллели, на мой взгляд, недостаточно для понимания соответствующего эпизода: помимо этнографических данных о шести пальцах как знаке демонической или колдовской природы [см.: 2], здесь важно упоминание дракона, очевидным образом отсылающее к Апокалипсису (Откр. І2) и, таким образом, включающее историю о шестипалом младенце в разветвленную сеть эсхатологических аллюзий и символов, пронизы-

7 Полностью это предложение у Афанасьева выглядит так: «Так как падучая, паралич, бешенство и другие болезни, сопровождаемые слабоумием, приписывались влиянию эльфов; то поэтому всякий ребенок, родившийся с физическими и душевными недостатками, в глазах суеверного народа был существо, в котором поселился нечистый дух, или прямо признавался за злого эльфа, которым подменено настоящее дитя при самом его рождении» [3, c. I06]. 
вающих последний роман Достоевского [см. об этом: I3, т. I5, с. 477-479; 8]. Тут же, впрочем, фигурирует и «смешение природы», что возвращает нас к двойственности восприятия младенцев-монстров в европейской культуре Нового времени.

Я, однако, хотел бы обратить внимание не только на топику, связанную со святотатством и христианской эсхатологией, очевидным образом определяющую специфические черты рассматриваемого сюжета, но и на еще один устойчивый мотив, а именно - публичную демонстрацию новорожденного черта, скажем так, в учреждениях культуры. Хотя этот мотив, казалось бы, имеет отчасти факультативный и хронологически поздний характер, на что указывал и Смирнов, именно он, судя по всему, играл решающую роль в «остенсивном» распространении легенды, если воспользоваться термином Линды Дег и Анджея Важони [52; 54]. Дело в том, что настойчивое желание посетителей Смитсоновского института и Ярославского музея увидеть новорожденного черта своими глазами имело, в общем-то, вполне законные социальные и культурные основания.

Одна из значимых и очень распространенных составляющих городской зрелищной культуры XIX в. (что в России, что в США, что в Западной Европе) - публичная демонстрация людей с необычной внешностью и курьезными телесными аномалиями ${ }^{8}$. В недавней работе Анник Морар, посвященной «показу монстров» в России Нового времени, убедительно доказывается, что эта форма массовых развлечений переживает свой расцвет во второй половине XIX в.:

В XIX веке в России культура монстров делает новый поворот. Успех, которым пользовались тогда демонстрации монстров в больших европейских городах, достиг и российских столиц. Примером этому служит огромный материал, изданный в России по случаю приезда в Москву в I858 году Юлии Пастраны, молодой женщины, тело которой было покрыто волосами. Она наверняка является одним из первых иностранных «монстров», которых показывали в России. За ней уже систематически приезжали и другие монстры, имевшие международную известность [2I]. 
Вполне допустимо, что непосредственным и наиболее важным социальным контекстом циркуляции сюжета о черте, родившемся в семье коммуниста, были не только массовые религиозные чувства, крестьянское иконопочитание, неприятие новой власти и ожидания конца света, но и городская зрелищная культура с ее акцентом на публичной демонстрации монструозности и телесных аномалий.

В этом контексте речь уже идет не столько о нравоучительной дидактике, сколько о совмещении идей и мотивов, понимаемых нами как религиозные, с топикой массовых развлечений. Эволюцию истории о новорожденном уродце, таким образом, можно рассматривать в контексте общей трансформации эмоциональных и когнитивных контекстов легендарных сюжетов на рубеже XIX и XX вв. Джилиан Беннет полагает, что содержательная специфика легенды подразумевает своего рода когнитивный диссонанс. Он формируется благодаря «совмещению привычного нам мировосприятия с чем-то совершенно иным либо объединению двух культурных категорий, которые для нас являются совершенно разными. Первая из этих коллизий лежит в основании историй о духах, чертях, святых и монстрах. Вторая, сочетающая, например, безопасность и угрозу, любовь и смерть, детство и жестокость, вызывает к жизни рассказы об маньяках, кастрированных детях, родителях, убивающих своих отпрысков, женщинах, лишающих жизни своих любовников. В общих чертах первая коллизия тяготеет к формированию “традиционных” легенд, а вторая - “современных” [47, c. XII]. По формулировке исследовательницы, одна из характерных особенностей «городской» или «современной» легенды по сравнению с предшествующими ей формами - постепенное выветривание мотивов, связанных с темой сверхъестественного, и включение новых культурных категорий, обладающих высоким эмоциональным значением для современного человека: «Персонажи и события в современных легендах чаще оказываются странными, пугающими и жуткими, чем открыто сверхъестественными; о них сообщают как о животрепещущих новостях о повседневной жизни, а не о потустороннем мире» [47, с. XII]. Думаю, что недолгая, но все же довольно примечательная история сюжета о новорожденном черте в советской культуре первой половины I920-х гг. позволяет говорить именно о процессах такого рода. 


\section{Список литературы}

I Антонов Д.А. Два «тела» иконы: апроприация силы у сакрального образа // Изображение и культ: сакральные образы в христианских традициях. Материалы научной конференции (Москва, РАНХиГС, I6-I7 июня 2017 г.) / отв. ред. и сост. Д.И. Антонов. М.: Издат. дом «Дело», 20I7. С. 5-13. Архипова А.С. Рога и копыта генералиссимуса: демонизация Сталина в советской и постсоветской традиции // In Umbra: Демонология как семиотическая система. Альманах. Вып. І / сост. Д.И. Антонов, О.Б. Христофорова. М.: РГГУ, 2012. C. $409-433$.

3 Афанасьев А.Н. Поэтические воззрения славян на природу. М.: Изд. К. Солдатенкова, I869. Т. 3. VII+840 c.

4 Бергер E.E. «Нехорошо, что монстры живут среди нас» (Амбруаз Паре о причинах врожденных аномалий) // Средние века. 2004. Вып. 65. С. І47-І65. Богданов К.А. Врачи, пациенты, читатели. Патографические тексты русской культуры. СПб.: Азбука-Аттикус, 2017. 669 с. Буйских Ю. «Кара Божья» и «Чудо Господнее» в рассказах об осквернении святынь в текстах современной украинской крестьянской традиции // Acta Baltico-Slavica. 38. Warszawa, 2014. P. 263-278.

7 Булычев А.А. Между святыми и демонами: Заметки о посмертной судьбе опальных Ивана Грозного. М.: Знак, 2005. 304 с.

8 Ветловская B.E. Достоевский и поэтический мир древней Руси // Труды отдела древнерусской литературы. Л.: Наука, 1974. Т. 28. С. 296-307.

9 Виноградова Л.Н. Подменыш // Славянские древности. Этнолингвистический словарь. М.: Международные отношения, 2009. Т. 4. С. 98-гоз.

Iо Власова М.Н. Русские суеверия. Энциклопедический словарь. СПб.: Азбука, І998. $672 \mathrm{c}$.

II Делюмо Ж. Грех и страх: Формирование чувства вины в цивилизации Запада (XIII-XVIII вв.) / пер. с франц. И.Б. Иткина, Е.Э. Ляминой, Е.И. Лебедевой, А.Г. Пазельской; под ред. Д.Э. Харитоновича. Екатеринбург: Изд-во Урал. ун-та, 2003. $572 \mathrm{c}$.

I2 Добровольская В.Е. Несказочная проза о разрушении церквей // Русский фольклор: материалы и исследования. СПб., І999. Т. ХХХ. С. 500-512.

I3 Достоевский Ф.М. Полн. собр. соч.: в $з$ т. Л.: Наука, I972-1990.

I4 Карначук Н.В. Новости о рождении чудовищ и английское общественное сознание второй половины XVI-XVII вв. // Диалог со временем. 20I4. Вып. 47. C. $107-\mathrm{I} 28$.

I5 Летопись Кунсткамеры. I7I4-I836 / авт.-сост. М.Ф. Хартанович, М.В. Хартанович; отв. ред. Н.П. Копанева, Ю.К. Чистов. СПб.: МАЭ РАН, 2ОІ4. 740 с.

I6 Львов А.Л. Соха и Пятикнижие: русские иудействующие как текстуальное сообщество. СПб.: Изд. Европейского ун-та в С.-Петербурге, 2013. 328 с. 
I7 Мазалова Н.Е. Состав человеческий: Человек в традиционных соматических представлениях русских. СПб.: Петербургское востоковедение, 200I. I92 с.

I8 Майзульс M. Наказание святых: благочестивое богохульство в Средние века и раннее Новое время // Государство, религия, церковь в России и за рубежом. 20I7. № 2 (35). С. 15-51.

I9 Майзульс M.P. Образ святого: quasi-присутствие и quasi-телесность // Изображение и культ: сакральные образы в христианских традициях. Материалы научной конференции (Москва, РАНХиГС, I6-I7 июня 20I7 г.) / отв. ред. и сост. Д.И. Антонов. М.: Издат. дом «Дело», 20I7. С. 68-75.

20 Мельникова Е.А. Эсхатологические ожидания рубежа XIX-XX веков: конца света не будет? // Антропологический форум. 2004. № I. С. 250-266.

2I Морар А. Одомашнить Иного: Показ монстров в России // НЛО. 20I7. № I43. URL: http://www.nlobooks.ru/node/825I. (дата обращения: о8.02.20I7).

22 Мороз А.Б. Устная история русской церкви в советский период (народные предания о разрушении церквей) // Ученые записки Российского православного университета ап. Иоанна Богослова. Вып. 6. М., 200о. С. І77-І85.

23 Памятники литературы Древней Руси. Начало русской литературы. XI - начало XII века / сост. и общ. ред. Д.С. Лихачева и Л.А. Дмитриева. М.: Худож. лит., I978. $4 \mathrm{I} 3 \mathrm{c}$.

24 Панченко А.А. Иван и Яков - необычные святые из болотистой местности: «Крестьянская агиология» и религиозные практики в России Нового времени. М.: Новое литературное обозрение, 2012. 442 с.

25 Пигин А.В. Из истории русской демонологии XVII века: Повесть о бесноватой жене Соломонии. СПб.: Дмитрий Буланин, г998. 267 с.

26 Пришвин М. Голубиная книга // Красная новь. I924. № 2. С. 228-236.

27 Ровинский Д.А. Русские народные картинки. СПб.: Императорская Академия наук, І88І. Кн. I-V.

28 Ровинский Д.А. Русские народные картинки. Посмертный труд печатан под наблюдением Н.П. Собко. СПб.: Изд. Р. Голике, г909. Т. І. 368 стб.

29 Смилянская Е.Б. Волшебники. Богохульники. Еретики. Народная религиозность и «духовные преступления» в России XVIII в. М.: Индрик, 2003. 464 с.

30 Смирнов В. Чорт родился (творимая легенда) // Труды Костромского научного общества исследователей местного края. 1923. Вып. 29. С. І7-20.

3 Т Тогоева О.И. «Истинная правда». Языки средневекового правосудия. М.: Наука, 2006. 333 c.

32 Топорков А.Л. Два издания книги П.Г. Богатырева «Магические действия, обряды и верования Закарпатья» (I929/I97I): научный и общественный контекст // Антропологический форум. 2011. № I4. С. I49-150.

33 Успенский Б.А. Филологические разыскания в области славянских древностей. М.: Изд. МГУ, І982. 248 с. 
Фадеева Л.В. Рассказы о разорении святыни в современной устной традиции Пинежья (К проблеме специфики сюжета и жанра) // Рябининские чтения 2003. Музей-заповедник «Кижи». Петрозаводск, 2003 URL: http://kizhi.karelia. $\mathrm{ru} /$ library/ryabinin-2003/29.html (дата обращения: 08.02.2017).

Фрэзер Дж. Дж. Золотая ветвь. М.: Политиздат, І986. 706 с. Шпренгер Я., Инститорис Г. Молот ведьм / пер. с лат. Н. Цветкова, предисл. С. Лозинского. Саранск: Саран. фил. СП «Норд», г99І. 349 с. Штырков С.А. Рассказы об осквернении святынь // Традиционный фольклор Новгородской области. (Пословицы и поговорки. Загадки. Приметы и поверья. Детский фольклор. Эсхатология (по записям І963-2002 гг.)) / сост. М.Н. Власова, В.И. Жекулина. СПб.: Тропа Троянова, 2006. С. 208-230.

A declaration of a strange and wonderfull monster: born in Kirkham parish in Lancashire...London: Jane Coe, I646. 8 p.

Addams J. The Long Road of Woman' Memory. New York: Macmillan, I9I6. XV+I68 p. Andrejev N.P. Die Legende vom Räuber Madej. Helsinki: Suomalainen Tiedeakatemia, I927 (Folklore Fellows Communications, vol. 69). 335 p.

Anemone A. The Monsters of Peter the Great: The Culture of the St. Petersburg Kunstkamera in the Eighteenth Century // The Slavic and East European Journal. 2000. Vol. 44. № 4. P. 583-602.

Another Museum Attraction // Perrysburg Journal (Ohio). I89I. January 24. P. I. Astuti R. What happens after death? // Questions of anthropology / ed. by R. Astuti, J. Parry and C. Stafford. Oxford, UK: Berg Publishers, 2007. P. 227-247.

Bates A.W. Emblematic Monsters: Unnatural Conceptions and Deformed Births in Early Modern Europe (Clio Medica 77). Amsterdam: Rodopi, 2005. VI+334 p.

5 Baughman E.W. Type and Motif-Index of the Folktales of England and North America. The Hague: Mouton, I966. LXXVIII+607 p.

6 Belanus B.J., Langlois J.L. Monstrous Births // Archetypes and motifs in folklore and literature: a handbook / ed. by Jane Garry and Hasan El-Shamy. Armonk, New York: M.E. Sharpe, 2005. P. 425-43I.

7 Bennet $G$. Bodies: Sex, violence, decease, and death in contemporary legend. Jackson: University Press of Mississippi, 2005. XV+3I3 p.

8 Bogdan R. Freak Show: Presenting Human Oddities for Amusement and Profit. Chicago and London: University of Chicago Press, $1988.336 \mathrm{p}$.

9 Boyer P. Religion Explained. The Human Instincts that Fashion Gods, Spirits and Ancestors. New York: Basic Books, 200I. VII+375 p.

Coleman H.J. Russian Baptists and Spiritual Revolution, I905-1929. Bloomington: Indiana University Press, 2005. XI+304 p.

I Crawford J. Marvelous Protestantism: Monstrous Births in Post-Reformation England. Baltimore: Johns Hopkins University, 2005. IX+270 p. 
52 Dégh L., Vázsonyi A. Does the Word “Dog” Bite? Ostensive Action: A Means of LegendTelling // Dégh L. Narratives in Society: A Performer-Centered Study of Narration. Helsinki, I995. P. 236-262.

53 Eberly S.S. Fairies and the Folklore of Disability: Changelings, Hybrids and the Solitary Fairy // Folklore. Vol. 99. № I (1988). P. 58-77.

54 Ellis B. Death by Folklore: Ostension, Contemporary Legend, and Murder // Western Folklore. Vol. 48. № 3 (July, I989). P. 20I-220.

55 Favret-Saada J. An Anthropology of Religious Polemics: The Case of Blasphemy Affairs // HAU: Journal of Ethnographic Theory. Vol. 6. № I (2016). P. 29-45. doi: IO.I43I8/ hau6.I.003.

56 Haffter C. The Changeling: History and Psychodynamics of Attitudes to Handicapped in European Folklore // Journal of the History of the Behavioral Sciences. I968. Vol. 3-4. P. 55-6I.

57 Hairy and Hoofed // St. Paul Sunday Globe (Minnesota). I89I. January I8. P. I.

58 Halpert H. Legends of the Cursed Child // New York Folklore Quarterly. 1958. Vol. XIV. № 3. P. 233-24I.

59 Halpert H., Mitchell B., Dickason D.H. Folktales from Indiana University Students // Hoosier Folklore Bulletin. Vol. I (1942). P. 85-97.

$60 \quad$ Has Hoofs and Hair: An Awful Monstrosity in Minnesota // The Columbus Journal (Nebraska). I891. January 28. P. I.

6I Hibbard L.A. Medieval Romance in England. New York: Burt Franklin, I963. VIII $+350 \mathrm{p}$.

62 Huet M.-H. Monstrous Imagination. Cambridge, MA: Harvard University Press, 1993. $316 \mathrm{p}$.

63 Lightner. Many Freak Curios // Pittsburg Dispatch (Pennsylvania). I89I. April I9. P. 7.

64 Locke J. A strange and lamentable accident that happened lately at Mears-Ashby in Northamptonshire. London: Harper and Wine, I642. 7 p.

65 Miles M. Martin Luther and Childhood Disability in I6th Century Germany: What did he write? What did he say? // Journal of Religion, Disability \& Health. 200I. Vol. 5 (4). P. 5-36.

66 Park K., Daston L.J. Unnatural Conceptions: The Study of Monsters in SixteenthCentury France and England // Past and Present. 198I. № 92. P. 20-54.

67 Park K., Daston L.J. Wonders and the Order of Nature (II5O-I75O). Boston: Zone Books, I998. 512 p.

68 Rose E.H. and H.J. Quebec Folklore Notes, III // Folklore. Vol. 24. № 3 (September I913). P. 360-362.

69 Semonin P. Monsters in the Marketplace: The Exhibition of Human Oddities in Early Modern England // Freakery: Cultural Spectacles of the Extraordinary Body / ed. by Rosemarie Garland Thompson. New York and London: New York University Press, 1996. P. 69-8I. 
70 Spinks J. Monstrous Births and Visual Culture in Sixteenth-Century Germany. London and New York: Routledge, 20I6. IX+207 p.

7I Viola L. The Peasant Nightmare: Visions of Apocalypse in the Soviet Countryside // Journal of Modern History. 1990. Vol. 62. № 4. P. 747-770.

72 Williams W. Monsters and their Meanings in Early Modern Culture: Mighty Magic. Oxford University Press, 20II. 344 p.

73 Wilson D. Signs and Portents: Monstrous Births from the Middle Ages to the Enlightenment. New York: Routledge, I993. 232 p.

74 Wrenshall L. Incantations and Popular Healing in Maryland and Pennsylvania // Journal of American Folklore. Vol. I5. № 59 (October-December 1902). P. 268-274.

75 Zhuk S. Russia's Lost Reformation: Peasants, Millennialism, and Radical Sects in Southern Russia and Ukraine, I830-I9I7. Baltimore: John Hopkins University Press, 2004. $\mathrm{XX}+457 \mathrm{p}$.

\section{References}

I Antonov D.A. Dva “tela” ikony: apropriatsiia sily u sakral'nogo obraza [The icon's two bodies: appropriating power of a sacred image]. Izobrazhenie i kul't: sakral'nye obrazy $v$ khristianskikh traditsiiakh. Materialy nauchnoi konferentsii [Image and cult: sacred images in Christian traditions. Conference proceedings]. Moscow, Izdatel'skii dom “Delo" Publ., 20I7, pp. 5-I3. (In Russ.)

2 Arkhipova A.S. Roga i kopyta generalissimusa: demonizatsiia Stalina v sovetskoi i postsovetskoi traditsii [The generalissimo's horns and hoofs: demonization of Stalin in Soviet and post-Soviet tradition]. In Umbra: Demonologiia kak semioticheskaia sistema. Al'manakh. [In Umbra: Demonology as a semiotic system]. Moscow, RGGU Publ., 20I2, issue I, pp. 409-433. (In Russ.)

3 Afanas'ev A.N. Poeticheskie vozzreniia slavian na prirodu [Poetic views on the nature of the Slavs]. Moscow, Izd. K. Soldatenkova Publ., I869. Vol. 3. VII+840 p. (In Russ.)

4 Berger E.E. "Nekhorosho, chto monstry zhivut sredi nas" (Ambruaz Pare o prichinakh vrozhdennykh anomalii) ["It is not good that monsters are among us" (Ambroise Paré about the causes of congenital defects)]. Srednie veka [Middle Ages], 2004, vol. 65, pp. I47-I65. (In Russ.)

$5 \quad$ Bogdanov K.A. Vrachi, patsienty, chitateli. Patograficheskie teksty russkoi kul'tury [Physicians, patients, readers. The pathographical texts of the Russian culture]. St. Petersburg, Azbuka-Attikus Publ., 20I4. 669 p. (In Russ.)

6 Buiskikh Iu. "Kara Bozh’ia” i “Chudo Gospodnee” v rasskazakh ob oskvernenii sviatyn' v tekstakh sovremennoi ukrainskoi krest'ianskoi traditsii [“God's punishment” and "the Lord's miracle" in the narratives about desecration of sacred objects recorded from present day Ukrainian peasants]. Acta Baltico Slavica, vol. 38, Warszawa, 20I4, pp. 263-278. (In Russ.) 
Bulychev A.A. Mezhdu sviatymi i demonami: Zametki o posmertnoi sud'be opal'nykh Ivana Groznogo [Between saints and demons. On the posthumous fate of the "disgraced" by Ivan the Terrible]. Moscow, Znak Publ., 2005. 304 p. (In Russ.)

8 Vetlovskaia V.E. Dostoevsky i poeticheskii mir drevnei Rusi [Dostoevsky and the poetic world of the Old Rus']. Trudy otdela drevnerusskoi literatury. [Proceedings of the Department of Old Russian Literature]. Leningrad, Nauka Publ., I974, vol. 28, pp. 296-307. (In Russ.)

9 Vinogradova L.N. Podmenysh [Changeling]. Slavianskie drevnosti. Etnolingvisticheskii slovar' [Slavic antiquities. Ethnolingiustic dictionary]. Moscow, Mezhdunarodnye otnosheniia Publ., 2009, vol. 4, pp. 98-I03. (In Russ.)

Io Vlasova M.N. Russkie sueveriia. Entsiklopedicheskii slovar' [Russian superstitions: an encyclopedia]. St. Petersburg, Azbuka Publ., I998. 672 p. (In Russ.)

II Delumeau J. Grekh i strakh: Formirovanie chuvstva viny v tsivilizatsii Zapada $\left(X I I I-X V I I I v v\right.$.). [Sin and fear: the emergence of the Western guilt culture, $\mathrm{I} 3^{\text {th }}-\mathrm{I} 8^{\text {th }}$ centuries]. Ekaterinburg, Izd-vo Ural. un-ta Publ., 2003. 572 p. (In Russ.)

I2 Dobrovol'skaia V.E. Neskazochnaia proza o razrushenii tserkvei [Folk narratives about the destruction of churches]. Russkii fol'klor: materialy i issledovaniia [Russian folklore: data and research], I999, vol. 30, pp. 500-512. (In Russ.)

I3 Dostoevsky F.M. Polnoe sobranie sochinenii: $v$ so $t$. [Complete works in 30 vols.]. Leningrad, Nauka Publ., I972-I990. (In Russ.)

I4 Karnachuk N.V. Novosti o rozhdenii chudovishch i angliiskoe obshchestvennoe soznanie vtoroi poloviny XVI-XVII vv. [News about monstrous births and English social consciousness in the second half of the $\mathrm{I} 6^{\text {th }}$ and the $17^{\text {th }}$ centuries]. Dialog so vremenem [Dialog with time], 20I4, no 47, pp. I07-I28. (In Russ.)

I5 Letopis' Kunstkamery. I7I4-I836 [The Kunstkamera chronicle. I7I4-I836]. St. Petersburg, MAE RAN Publ., 20I4. 740 pp. (In Russ.)

I6 L'vov A.L. Sokha i Piatiknizhie: russkie iudeistvuiushchie kak tekstual'noe soobshchestvo [Plow and Pentateuch: Russian Judaizants as a textual community] St. Petersburg, Izd. Evropeiskogo universiteta v S.-Peterburge Publ., 20I3. 328 p. (In Russ.)

I7 Mazalova N.E. Sostav chelovecheskii: Chelovek v traditsionnykh somaticheskikh predstavleniiakh russkikh [Human composition: a human being in the traditional somatic conception of the Russians]. St. Petersburg, Peterburgskoe vostokovedenie Publ., 200I. I92 p. (In Russ.)

I8 Maizul's M. Nakazanie sviatykh: blagochestivoe bogokhul'stvo v Srednie veka i rannee Novoe vremia [Punishment of saints: pious blasphemy in the medieval and early Modern culture]. Gosudarstvo, religiia, tserkov'v Rossii i za rubezhom [State, religion, and society in Russia and abroad], 20I7, no 2 (35), pp. 15-5I. (In Russ.)

I9 Maizul's M.R. Obraz sviatogo: quasi-prisutstvie i quasi-telesnost' [Images of saints: quasi-presence and quasi-corporality]. Izobrazhenie i kul't: sakral'nye obrazy $v$ khristianskikh traditsiiakh. Materialy nauchnoi konferentsii (Moskva, RANKhiGS, 
I6-I7 iiunia 20I7 g.) [Image and cult: sacred images in Christian traditions. Conference proceedings]. Moscow, Izdatel'skii dom “Delo” Publ., 20I7, pp. 68-75. (In Russ.) Mel'nikova E.A. Eskhatologicheskie ozhidaniia rubezha XIX-XX vekov: kontsa sveta ne budet? [Eschatological Expectations at the turn of the $19^{\text {th }}-2 \mathrm{O}^{\text {th }}$ centuries: the end of the world is (not) nigh?]. Antropologicheskii forum [Forum for anthropology], 2004, no I, pp. 250-266. (In Russ.) Morar A. Odomashnit’ Inogo: Pokaz monstrov v Rossii [domesticating the other: freak shows in Russia]. Novoe literaturnoe obozrenie, 20I7, no I43. Available at: http://www. nlobooks.ru/node/825I. Accessed on 08.02.20I7 (Accessed o8 February, 20I7). (In Russ.)

Moroz A.B. Ustnaia istoriia russkoi tserkvi v sovetskii period (narodnye predaniia o razrushenii tserkvei) [Oral history of the Russian Orthodox Church in the Soviet period (local legends about the church destruction)]. Uchenye zapiski Rossiiskogo pravoslavnogo universiteta ap. Ioanna Bogoslova [Proceedings of the Apostle John Theologian Russian Orthodox University]. Moscow, 2000, vol. 6, pp. I77-I85. (In Russ.)

23 Pamiatniki literatury Drevnei Rusi. Nachalo russkoi literatury. XI - nachalo XII veka [Heritage of Old Russian literature. The beginning of Russian literature, $\mathrm{II}^{\text {th }}-$ early

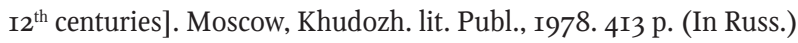

Panchenko A.A. Ivan i Iakov - neobychnye sviatye iz bolotistoi mestnosti:

"Krest'ianskaia agiologiia" i religioznye praktiki v Rossii Novogo vremeni [Ivan and Iakov - unusual saints from a marshland: "Popular hagiology and religious practices in modern Russia”]. Moscow, Novoe literaturnoe obozrenie Publ., 20I2. 442 p. (In Russ.) Pigin A.V. Iz istorii russkoi demonologii XVII veka: Povest' o besnovatoi zhene Solomonii [From the history of Russian demonology: The story about Solomonia, a possessed woman]. St. Petersburg, Dmitrii Bulanin Publ., I998. 267 p. (In Russ.) Prishvin M. Golubinaia kniga [The Dove book]. Krasnaia nov', I924, no 2, pp. 228-236. (In Russ.) Rovinskii D.A. Russkie narodnye kartinki [Russian popular prints]. St. Petersburg, Imperatorskaia Akademiia nauk Publ., I88I, vol. I-V. (In Russ.)

28 Rovinskii D.A. Russkie narodnye kartinki [Russian popular prints]. St. Petersburg, Izd. R. Golike Publ., I909. Vol. I. 368 p. (In Russ.)

29 Smilianskaia E.B. Volshebniki. Bogokhul'niki. Eretiki. Narodnaia religioznost' $i$ “dukhovnye prestupleniia" $v$ Rossii XVIII $v$. [Witches, blasphemers, and heretics: Popular religiosity and "spiritual crimes" in the $18^{\text {th }}$ century Russia]. Moscow, Indrik Publ., 2003. 464 p. (In Russ.)

30 Smirnov V. Chort rodilsia (tvorimaia legenda) [A devil is born. (Contemporary legend)]. Trudy Kostromskogo nauchnogo obshchestva issledovatelei mestnogo kraia [Proceedings of the Kostroma learned society for the study of the region], I923, vol. 29, pp. I7-20. (In Russ.) 
3I Togoeva O.I. "Istinnaia pravda". Iazyki srednevekovogo pravosudiia ["Veritable truth". Languages of medieval justice]. Moscow, Nauka Publ., 2006. 333 p. (In Russ.)

32 Toporkov A.L. Dva izdaniia knigi P.G. Bogatyreva "Magicheskie deistviia, obriady i verovaniia Zakarpat'ia” (I929/I97I): nauchnyi i obshchestvennyi kontekst [Two editions of the book by P. G. Bogatyrev "Magic, rituals and beliefs in the Transcarpathian region”: scholarly and public contexts]. Antropologicheskii forum [Forum for anthropology], 20II, no I4, pp. I49-150. (In Russ.)

33 Uspenskii B.A. Filologicheskie razyskaniia v oblasti slavianskikh drevnostei [Philological studies of the Slavic antiquities]. Moscow, Izd. MGU Publ., I982. 248 p. (In Russ.)

34 Fadeeva L.V. Rasskazy o razorenii sviatyni v sovremennoi ustnoi traditsii Pinezh’ia (K probleme spetsifiki siuzheta i zhanra) [Narratives about the destruction of sacred objects in present day Pinega oral tradition (On the specificity of the plot and the genre)]. Riabininskie chteniia - 2003 [Ryabinin readings - 2003]. Petrozavodsk, Muzei-zapovednik “Kizhi” Publ., 2003. Available at: http://kizhi.karelia.ru/library/ ryabinin-2003/29.html (Accessed o8 February 20I7). (In Russ.)

35 Frazer J.J. Zolotaia vetv" [The golden bough]. Moscow, Politizdat Publ., I986. 706 p. (In Russ.)

36 Sprenger J., Institoris G. Molot ved'm [The hammer of witches]. Saransk, Saran. fil. SP "Nord” Publ., I99I. 349 p. (In Russ.)

37 Shtyrkov S.A. Rasskazy ob oskvernenii sviatyn' [Narratives about sacrilege of sacred places]. Traditsionnyi fol'klor Novgorodskoi oblasti [Traditional folklore of the Novgorod region]. St. Petersburg, Tropa Troianova Publ., 2006, pp. 208-230. (In Russ.)

38 A declaration of a strange and wonderfull monster: born in Kirkham parish in Lancashire... London, Jane Coe, I646. 8 p. (In English)

39 Addams J. The Long Road of Woman' Memory. New York, Macmillan, I9I6. XV+I68 p. (In English)

40 Andrejev N.P. Die Legende vom Räuber Madej. Helsinki, Suomalainen Tiedeakatemia, I927 (Folklore Fellows Communications, vol. 69). 335 p. (In German)

4I Anemone A. The Monsters of Peter the Great: The Culture of the St. Petersburg Kunstkamera in the Eighteenth Century. The Slavic and East European Journal, 2000, vol. 44, no 4, pp. 583-602. (In English)

42 Another Museum Attraction. Perrysburg Journal (Ohio), I89I, January 24, p. I. (In English)

43 Astuti R. What happens after death? Questions of anthropology, ed. by R. Astuti, J. Parry and C. Stafford Oxford, UK, Berg Publishers, 2007, pp. 227-247. (In English)

44 Bates A.W. Emblematic Monsters: Unnatural Conceptions and Deformed Births in Early Modern Europe (Clio Medica 77). Amsterdam, Rodopi, 2005. VI+334 p. (In English)

45 Baughman E.W. Type and Motif-Index of the Folktales of England and North America. The Hague, Mouton, 1966. LXXVIII+607 p. (In English) 
46 Belanus B.J., Langlois J.L. Monstrous Births. Archetypes and motifs in folklore and literature: a handbook, ed. by Jane Garry and Hasan El-Shamy. Armonk, New York, M.E. Sharpe, 2005, pp. 425-43I. (In English) Bennet G. Bodies: Sex, violence, decease, and death in contemporary legend. Jackson, University Press of Mississippi, 2005. XV+3I3 p. (In English)

48 Bogdan R. Freak Show: Presenting Human Oddities for Amusement and Profit. Chicago and London, University of Chicago Press, I988. 336 p. (In English)

49 Boyer P. Religion Explained. The Human Instincts that Fashion Gods, Spirits and Ancestors. New York, Basic Books, 200I. VII+375 p. (In English)

50 Coleman H.J. Russian Baptists and Spiritual Revolution, 1905-1929. Bloomington, Indiana University Press, 2005. XI+304 p. (In English)

5I Crawford J. Marvelous Protestantism: Monstrous Births in Post-Reformation England. Baltimore, Johns Hopkins University, 2005. IX+270 p. (In English)

52 Dégh L., Vázsonyi A. Does the Word “Dog” Bite? Ostensive Action: A Means of Legend-Telling. Dégh L. Narratives in Society: A Performer-Centered Study of Narration. Helsinki, I995, pp. 236-262. (In English)

53 Eberly S.S. Fairies and the Folklore of Disability: Changelings, Hybrids and the Solitary Fairy. Folklore, vol. 99, no I (I988), pp. 58-77. (In English)

54 Ellis B. Death by Folklore: Ostension, Contemporary Legend, and Murder. Western Folklore, vol. 48, no 3 (July, I989), pp. 20I-220. (In English)

55 Favret-Saada J. An Anthropology of Religious Polemics: The Case of Blasphemy Affairs. HAU: Journal of Ethnographic Theory, vol. 6, no I (2016), pp. 29-45. doi: IO.I4318/hau6.I.003. (In English)

56 Haffter C. The Changeling: History and Psychodynamics of Attitudes to Handicapped in European Folklore. Journal of the History of the Behavioral Sciences, I968, vol. 3-4, pp. 55-6I. (In English)

57 Hairy and Hoofed. St. Paul Sunday Globe (Minnesota), I89I, January I8, p. I. (In English)

58 Halpert H. Legends of the Cursed Child. New York Folklore Quarterly, I958, vol. XIV, no 3, pp. 233-24I. (In English)

59 Halpert H., Mitchell B., Dickason D. H. Folktales from Indiana University Students. Hoosier Folklore Bulletin, vol. I (I942), pp. 85-97. (In English)

60 Has Hoofs and Hair: An Awful Monstrosity in Minnesota. The Columbus Journal (Nebraska), I89I, January 28, p. I. (In English)

6I Hibbard L.A. Medieval Romance in England. New York, Burt Franklin, I963. VIII+350 p. (In English)

62 Huet M.-H. Monstrous Imagination. Cambridge, MA, Harvard University Press, 1993. 3I6 p. (In English)

63 Lightner. Many Freak Curios. Pittsburg Dispatch (Pennsylvania), I89I, April I9, p. 7. (In English) 
64 Locke J. A strange and lamentable accident that happened lately at Mears-Ashby in Northamptonshire. London, Harper and Wine, I642. 7 p. (In English)

65 Miles M. Martin Luther and Childhood Disability in I6th Century Germany: What did he write? What did he say? Journal of Religion, Disability E Health, 200I, vol. 5 (4), pp. 5-36. (In English)

66 Park K., Daston L.J. Unnatural Conceptions: The Study of Monsters in SixteenthCentury France and England. Past and Present, I98I, no 92, pp. 20-54. (In English)

67 Park K., Daston L.J. Wonders and the Order of Nature (II5O-I750). Boston, Zone Books, I998. 512 p. (In English)

68 Rose E.H. and H.J. Quebec Folklore Notes, III. Folklore, vol. 24, no 3 (September I9I3), pp. 360-362. (In English)

69 Semonin P. Monsters in the Marketplace: The Exhibition of Human Oddities in Early Modern England. Freakery: Cultural Spectacles of the Extraordinary Body, ed. by Rosemarie Garland Thompson. New York and London, New York University Press, I996, pp. 69-8I. (In English)

70 Spinks J. Monstrous Births and Visual Culture in Sixteenth-Century Germany. London and New York, Routledge, 20I6. IX+207 p. (In English)

7I Viola L. The Peasant Nightmare: Visions of Apocalypse in the Soviet Countryside. Journal of Modern History, I990, vol. 62, no 4, pp. 747-770. (In English)

72 Williams W. Monsters and their Meanings in Early Modern Culture: Mighty Magic. Oxford University Press, 20II. 344 p. (In English)

73 Wilson D. Signs and Portents: Monstrous Births from the Middle Ages to the Enlightenment. New York, Routledge, I993. 232 p. (In English)

74 Wrenshall L. Incantations and Popular Healing in Maryland and Pennsylvania. Journal of American Folklore, vol. I5, no 59 (October-December I902), pp. 268-274. (In English)

75 Zhuk S. Russia's Lost Reformation: Peasants, Millennialism, and Radical Sects in Southern Russia and Ukraine, I830-I9I7. Baltimore, John Hopkins University Press, 2004. $\mathrm{XX}+457$ p. (In English) 